\title{
Limnological Studies Related to Physico-Chemical Characteristics of Water of Santragachi and Joypur Jheel, W.B., India
}

\author{
A. Patra ${ }^{1}$, K.B. Santra ${ }^{2 *}$ and C.K. Manna ${ }^{1}$ \\ ${ }^{1}$ Endocrinology Laboratory, Department of Zoology, University of Kalyani, Kalyani- 741235, Nadia, W.B., India \\ ${ }^{2}$ Daulatpur High School (H.S.), Daulatpur, Dakshin Dinajpur, W.B., India \\ *E-mail: kalyan_117@rediffmail.com
}

Received: 03.10.2010, Accepted: 28.11.2010

\begin{abstract}
The present study deals with the seasonal limnological investigation related to physico-chemical characteristics of water of the Santragachi and Joypur Jheel, West Bengal, India. Besides temperature and meteorological data, 17 limnological parameters were tested following standard methods at 3 sampling sites/stations of each Jheel. The physico-chemical parameters (transparency, pH, DO, BOD, COD, free $\mathrm{CO}_{2}$, total alkalinity, conductivity, $\mathrm{CaCO}_{3}$, TSS, TDS, Chloride, Ammonia, Nitrite, Nitrate, Phosphate, etc.) showed distinct temporal or seasonal variation in both the Jheels. Higher nutrient contents (nitrate, phosphate) are present in Santragachi Jheel. This finding also signifies eutrophication/higher trophic level. Water transparency, dissolved oxygen, $\mathrm{BOD}$, total alkalinity, conductivity, $\mathrm{CaCO}_{3}$ hardness, TSS, nitrate and phosphate was correlated with various physico-chemical parameters in both the Jheels. The physico-chemical characteristics of water of the two Jheels revealed the poor water quality in Santragachi Jheel than the Joypur Jheel. These characteristics showed maximum contamination of water due to sewage effluents in Santragachi Jheel. The two years (February, 2000 - January, 2002) survey reflects higher degree of pollution in Santragachi Jheel.
\end{abstract}

Key words: Limnology, physico-chemical, Santragachi, Joypur

\section{Introduction}

Wetlands i.e., lakes, jheels, beels etc., have a variety of linkages for energy and nutrient exchange with surrounding watersheds and air sheds. The inland freshwater ecosystems both lentic and lotic, are being increasingly subjected to greater stress from various human activities (Wood and Gibson, 1974; Hemasundaram, 2003). The eutrophication of water means enrichment with nutrients and the resulting degradation of its quality accompanied by luxuriant growth of micro and macrophytes, is recognized as a major problem in the developed as well as in developing countries. The enrichment of nutrients occurs due to the disposal of domestic and farm sewage, industrial effluents and from the runoff from surrounding areas. Vollenweider (1968) pointed out that the domestic sewage is a major source of eutrophication.

With the constantly increasing eutrophication of surface waters more and more attention is being paid to investigations on the bottom sediments of 
A Patra, K.B. Santra and C.K. Manna / Our Nature (2010) 8: 185-203

wetlands (Kajak, 1979; Goltermon and Oude, 1991; Freeman et al., 1993; Clair et al., 1996; Dortch, 1996; Craft, 1997; Ansari and Kumar, 2003).

The biology, ecology and physicochemical characteristics of aquatic habitats have been studied in detail in India by Sharma et al. (1978). A good amount of work has been done on different aspects of limnology of Himalayan lakes (Qadri and Yousuf, 1978; Sharma and Pant, 1979; Negi and Pant, 1983; Sarwar and Wazir, 1991; Sharma et al., 2003; Sharma and Verma, 2003). On the limnology of water bodies in southern India, the works of Ganapati (1957); Seshavatharam and Venu (1982); Ramana and Sreeramalu (1994); and Sivakumar et al. (2003) are worth mentioning. Limnological studies of polluted water bodies were studied by Sharma et al. (1978); Bhatt and Pathak (1989); Varghese et al. (1992); Das and Sinha (1994); Swaranlatha and Narsing Rao (1998); Hemasundaram et al. (2003); Jakher and Rawat (2003); Jothimani and Bhaskaran (2003); and Patralekh and Patralekh (2004).

Although considerable investigations have been made by the researchers but a little information is known about the systematic limnological studies in SouthernWest Bengal. However, it is important to note that no qualitative, quantitative or ecological study on limnology was made so far from Santragachi and Joypur Jheel. Of the two Jheels, Santragachi Jheel has received various types of sewage i.e., domestic sewage, cattle shed sewage etc. Hence an attempt into the limnological investigation in relation to the different physico-chemical characteristics of water of the two Jheels was undertaken in the present investigation for a period of two years (February, 2000 - January, 2002).

\section{Materials and methods Study area}

Santragachi Jheel (SJ) $\left(22^{\circ} 58^{\prime} \mathrm{N}\right.$ and $88^{\circ} 27^{\prime} \mathrm{E}$ ) (Fig.1) is one of the most important urban wetlands of the district Howrah, W.B., India. It is locally known as 'Makal Jheel', located on the southern side of Santragachi Railway Station of the South Eastern Railway, Govt. of India. Another important natural rural wetland is Joypur Jheel (JJ) also known as Belanagar Wetland (NEWS, 1996), situated at the junction of Delhi (NH-2) and Bombay (NH-6) highway near Belanagar Railway Station of Eastern Railway, Govt. of India.

The total area of the SJ and JJ are 10.87 and 11.54 hectares, respectively. SJ is roughly rectangular in shape with length about $915 \mathrm{~m}$, width $305 \mathrm{~m}$, perimeter 2418 $\mathrm{m}$., and mean depth from 4-7 ft. JJ is almost oval in shape with maximum length $854 \mathrm{~m}$ from north to south and maximum width $342 \mathrm{~m}$ from east to west, perimeter $3254 \mathrm{~m}$, and mean depth from 4-12 ft. The SJ has been owned by South-Eastern Railways, but since August, 1992 the Wild-life wing of the Forest Department, Govt. of West Bengal has taken up management and developmental work of this wetland. Later on, it would be included under a Special Wetland Circle of the Forest Department which is yet to be constituted. In the early of 1975, JJ was the property of the Eastern Railway, Govt. of India, but in July 1975, it has been owned by the Dept. of Forest, Govt. of West Bengal, India. Excessive fishing and washing of buffaloes are putting constraints on the biodiversity of this wetland. There are a number of shops on the southern side along the highways which release their garbage into $\mathrm{JJ}$ wetland. Big cattle shed nearby in the eastern side of the $\mathrm{JJ}$ release its sewage into it. Reclamation of 
A Patra, K.B. Santra and C.K. Manna / Our Nature (2010) 8: 185-203

part of the wetland along drying margins during premonsoon season for agriculture is another main threat.

\section{Sampling sites}

To study the limnological changes, regular samplings of water were done fortnightly during February, 2000 - January, 2002 from three selected sites/stations of each jheel as follows:

\section{Santragachi Jheel}

Station 1(S1): Located at the western side of the jheel near the commercial cattle shed. Several sewage points are located on this side.

Station 2(S2): Located at the middle of southern side and this station is devoid of sewage points.

Station 3 (S3): Located at the eastern side. Most of the major sewage points are located on this side.

\section{Joypur Jheel}

Station 1(J1): Located at the eastern side near the W.B. Govt. nursery.

Station 2(J2): Located at the northern side and commercial cattle shed is located on this side.

Station $3(\mathrm{~J} 3)$ : Located at the southern side near railway track of the Eastern Railway.

\section{Data collection and analysis of water}

Collection of atmospheric/meteorological data

Temperature of air was recorded by a digital centigrade thermometer $\left(-50^{\circ} \mathrm{C}\right.$ to $\left.+150^{\circ} \mathrm{C}\right)$ on the date of sampling. Besides maximum and minimum air temperature, relative humidity and rainfall, photoperiod during the study period (February, 2000 - January, 2002) were collected from the Meteorological Office, Kolkata. The average values of the data recorded during the period 2000-2002 were represented on a monthly basis to get an overview of the climatic condition of the study area.

Collection and preservation of water samples

Water samples were collected fortnightly in clear glass bottles from surface (max. depth $20 \mathrm{~cm}$ ) and vegetated zone of three different sites/stations of the Jheels. Water samples were collected in three replicates from surface, column and bottom of each station and mean values of all three observations were taken into consideration. For BOD estimation, water samples were collected separately in dark bottles.

Physico-chemical parameters like water temperature, $\mathrm{pH}, \mathrm{DO}$, free Carbon-dioxide, total alkalinity and conductivity were measured in the field. Other parameters were mostly tested within $24 \mathrm{hrs}$ of collection. Preservation of water samples was done at $4^{\circ} \mathrm{C}$ temperature.

\section{Analysis of water sample}

A total of 17 limnological parameters of water viz., temperature, transparency, $\mathrm{pH}$, dissolved oxygen, biological oxygen demand, chemical oxygen demand, free Carbon-di-oxide, total alkalinity, conductivity, $\mathrm{CaCO}_{3}$ hardness, total suspended solid, total dissolved solid, chloride, ammonia, nitrite, nitrate and phosphate were determined.

All the parameters were analyzed following the standard methods (Golterman, 1969; Michael, 1984; Trivedi and Goel, 1984; APHA, 1989) and by spectrophotometer SQ 118. Pearson's correlation coefficients were calculated for the determination of relationships between different types of physico-chemical 


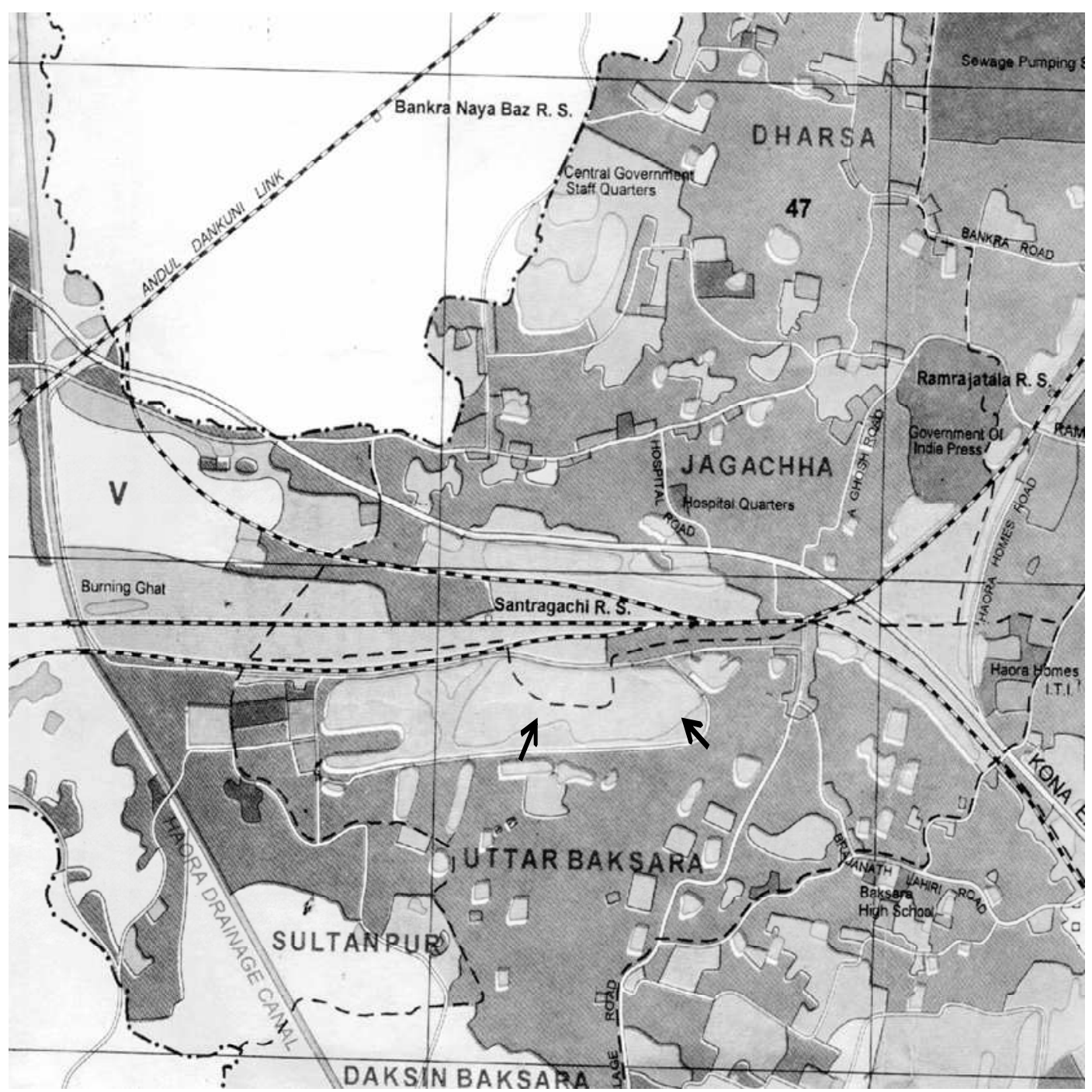

Figure1: Location of Santragachi Jheel

characteristics of water. The correlations were tested at 5 and $1 \%$ level of significance. The analysis was done by software programme, SPSS, version 6.0.

\section{Results}

\section{Climatic condition}

In different tropical countries as well as in India three distinct seasons are usually observed. They are: premonsoon (summer), monsoon and post monsoon (winter). In West Bengal, premonsoon (March - June) is characterized by higher air temperature, longer day time and occasional rain. The 
monsoon season (July - September) has higher humidity and rainfall and relatively shorter day time. On the other hand the post monsoon (October - February) is characterized by lower air temperature, shorter day time and lesser precipitation.

\section{Ambient temperature}

The mean maximum temperature was noticed in April, 2000, $35.88^{\circ} \mathrm{C}$ and minimum in December, 2001, $23.12^{0} \mathrm{C}$ (Fig. 2A1). Mean minimum daily temperature was minimum, $15.04^{0} \mathrm{C}$ in January, 2002 and maximum in May 2001, $32.14^{0} \mathrm{C}$.

\section{Humidity}

Maximum relative humidity varied from $86.48 \%$ to $97.13 \%$. Humidity was maximum in September, $2000(97.13 \%)$ and minimum in February, 2000 (86.48\%) (Fig. 2A2).Daily minimum humidity was maximum in August, 2001(75.14\%) and minimum in January, 2001(42.8\%).

\section{Rainfall}

Maximum total monthly rainfall was recorded in September, 2001(514.30 mm) and minimum in December and January, 2000 (nil) (Fig. 2B1).

\section{Photoperiod}

The length of day ranged from 638 to 808 minutes. The maximum mean day length was recorded in June, 2000 and minimum in December, 2001(Fig. 2B2).

\section{Physico-chemical characteristics of water Santragachi Jheel:}

The average range and station wise monthly variations of different physico-chemical characteristics of water of the Santragachi Jheel are represented in Table (1) and figures $(3 \mathrm{~A}-3 \mathrm{Q})$ respectively.
The water temperature followed the same trend at all three sites of the Jheel (Fig. 3A). Trend of monthly fluctuation in the surface water temperature was exactly identical to that of the atmospheric temperature. The temperature remained minimum during the winter season (around $19^{\circ} \mathrm{C}$ ). It was increased during the summer months to a maximum (around $33^{\circ} \mathrm{C}$ ). The temperature had been observed to be highest $\left(33.22^{\circ} \mathrm{C}\right)$ during the beginning of study (May, 2000) at site S2. The transparency did not show any definite seasonal pattern at three sites. It was observed to be very low $(22.60 \mathrm{~cm})$ in June, 2002 at site S3 but increased slightly during winter season (Fig. $3 \mathrm{~B})$. The $\mathrm{pH}$ had been found to be highest at the beginning of the study. The value ranged from 7.14 to 8.58 (Fig. 3C). It increased slightly during the following rainy season. The dissolved oxygen content was observed to be maximum at site S2 (Fig. 3D).

The dissolved oxygen value ranged from $2.39 \mathrm{mg} / \mathrm{l}$ (site $\mathrm{S} 3$ ) to $8.73 \mathrm{mg} / \mathrm{l}$ (site S2). The value of dissolved oxygen decreased during summer and increased in winter season. BOD values ranged from $9.11 \mathrm{mg} / \mathrm{l}$ at site S2 during February, 2000 to $50.93 \mathrm{mg} / \mathrm{l}$ at site $\mathrm{S} 3$ during June, 2001(Fig. 3E). BOD values became higher during the summer months and its value was lower at site $\mathrm{S} 2$ than the value at site $\mathrm{S} 1$ and S3. Increased BOD values were further observed in the second year of study. The chemical oxygen demand was minimum in February, $2000(38.8 \mathrm{mg} / \mathrm{l})$ at site S2 and maximum in summer $(272 \mathrm{mg} / \mathrm{l})$ at site $\mathrm{S} 3$ (Fig. 3F). However, the values were comparatively higher during the summer periods. The free $\mathrm{CO}_{2}$ showed peak during the summer period $(11.24 \mathrm{mg} / \mathrm{l}$ at site $\mathrm{S} 3)$. High values of total alkalinity were 
A Patra, K.B. Santra and C.K. Manna / Our Nature (2010) 8: 185-203

observed during summer and rainy season (Fig. 3H). It was lower in winter season at all three sites. Highest peak was observed at site S3 (233 mg/l) in July, 2001 and lowest value was recorded at site $\mathrm{S} 2(129.79 \mathrm{mg} / \mathrm{l})$ in February, 2000. Conductivity varied from $412.20 \mu \mathrm{mhos} / \mathrm{cm}$ at site $\mathrm{S} 2$ during February, 2000 to $1536.80 \mu \mathrm{mhos} / \mathrm{cm}$ at site S3 during July, 2001(Fig. 3I). In general it was higher at $\mathrm{S} 1$ and $\mathrm{S} 3$ sites than the $\mathrm{S} 2$ site. Conductivity decreased during winter season followed by progressive increase during summer. The value of $\mathrm{CaCO}_{3}$ hardness was higher at $\mathrm{S} 1$ and $\mathrm{S} 3$ sites than S1 site (Fig 3J). The maximum mean values were recorded during summer $(299.12 \mathrm{mg} / \mathrm{l})$ at S3 site which had a decreasing trend in monsoon and lowest in winter. The lowest value of $\mathrm{CaCO}_{3}$ hardness was observed at S2 site $(140.81 \mathrm{mg} / \mathrm{l})$ during November, 2001. The maximum value appeared in summer at S3 site $(264.54 \mathrm{mg} / \mathrm{l})$ and the minimum value was recorded in winter at S2 site (108.02 mg/l) (Fig. 3K).

Total dissolved solids (TDS) were observed to be minimum during monsoon and maximum values were recorded during the summer season (Fig. 3L). The chloride content at three sites showed little variation during the winter and early summer seasons (Fig. 3M). It sharply increased during the summer months showing distinct peaks $(159.80 \mathrm{mg} / \mathrm{l}$ at $\mathrm{S} 1$ site, $92.00 \mathrm{mg} / \mathrm{l}$ at $\mathrm{S} 2$ site and $191.40 \mathrm{mg} / \mathrm{l}$ at $\mathrm{S} 3$ site), but later declined abruptly during the rainy season.

The values of ammonia increased sharply from winter season to summer months (Fig. 3N). Nitrite did not show any definite seasonal pattern at three sites (Fig. 30). The nitrate content at three sites remained maximum during winter and decreases with the beginning of the summer (Fig. 3P). The phosphate content at three sites was observed to be highest during summer season and decreased steeply through the rainy season (Fig. 3Q).

\section{Joypur Jheel:}

The average range and station wise monthly variations of different physico-chemical characteristics of water of the Joypur Jheel are represented in table 1.

The water temperature was observed to be minimum $\left(19.62^{\circ} \mathrm{C}\right)$ during winter season (January, 2001 at $\mathrm{J} 2$ site) and the peak $\left(33.44^{\circ} \mathrm{C}\right)$ was attained during May, 2000 at J3 site. The transparency was lowest at $\mathrm{J} 2$ site $(54.67 \mathrm{~cm})$ during summer season (June, 2000) and highest during winter period (January, 2002) at J3 site of Joypur Jheel . The $\mathrm{pH}$ remained higher during winter season at all sites and lowest in October, 2000 at $\mathrm{J} 2$ site (7.60).

Dissolved oxygen content was higher $(15.61 \mathrm{mg} / \mathrm{l})$ at $\mathrm{J} 3$ site during September, 2000. It was sharply decreased $(5.73 \mathrm{mg} / \mathrm{l})$ during summer months (June, 2001) at J2 site in Joypur Jheel. The peak values of BOD content were observed in June, 2001 with the concentration of $21.48 \mathrm{mg} / \mathrm{l}$ at $\mathrm{J} 2$ site. Low values were appeared during January, 2001(4.12 mg/l) at J3 site. The COD was observed to be lowest during the winter periods, $2002(19.27 \mathrm{mg} / \mathrm{l}$ at J3 site) and maximum in the summer months, 2000 $(68.34 \mathrm{mg} / \mathrm{l})$ at $\mathrm{J} 2$ site. Maximum values of free $\mathrm{CO}_{2}$ were observed during summer months, 2000 ( $2.74 \mathrm{mg} / \mathrm{l}$ at J2 site). Free $\mathrm{CO}_{2}$ was completely absent during the winter season at all three sites. The total alkalinity remained low during January, $2002(114.94 \mathrm{mg} / \mathrm{l})$ at J3 site. It was increased to a maximum in June, 2001 $(144.41 \mathrm{mg} / \mathrm{l})$ at $\mathrm{J} 2$ site. At site $\mathrm{J} 2$, the content was higher than the other two sites. Conductivity was seen to be maximum in 
the month of June in both the annual cycles and the value was more in the second annual cycle of the study period. The maximum value, however, was recorded at J2 site during June, 2000 $(550.67 \mu \mathrm{mhos} / \mathrm{cm})$. The minimum value was seen to be during February, 2001 (303.33 $\mu \mathrm{mhos} / \mathrm{cm}$ at $\mathrm{J} 3$ site). The $\mathrm{J} 2$ site had slightly higher conductivity than the other two sites. Maximum value of hardness of water was observed $(137.04 \mathrm{mg} / \mathrm{l})$ during June, 2000 at $\mathrm{J} 2$ site. The $\mathrm{CaCO}_{3}$ hardness value recorded its minima at site $\mathrm{J} 3$ (101.72 $\mathrm{mg} / \mathrm{l}$ ) during January, 2001. The average values showed highest level in summer followed by progressive decrease in winter season.

Total suspended solid content was observed to be maximum $(153.07 \mathrm{mg} / \mathrm{l})$ at $\mathrm{J} 2$ site during summer season and minimum during winter months. There was no marked difference in the TSS at two sites, i.e., J1 and J3. The total dissolved solid content was low $(121.80 \mathrm{mg} / \mathrm{l})$ during winter season at $\mathrm{J} 3$ site. It increases in the summer season and attained a maximum $(332.39 \mathrm{mg} / \mathrm{l})$ at $\mathrm{J} 2$ site. The value was again low in the following rainy season. The chloride content was minimum during the beginning of the study $(69.88 \mathrm{mg} / \mathrm{l}$ at $\mathrm{J} 3$ site in February, 2000). Thereafter, it became high during summer $(138.28 \mathrm{mg} / \mathrm{l}$ at $\mathrm{J} 2$ site in June, 2001). Lowest values of chloride were recorded in winter season. The ammonia was maximum during summer. Highest value was observed at $\mathrm{J} 2$ site in June, 2001 $(2.17 \mathrm{mg} / \mathrm{l})$.

The value of ammonia was minimum in winter season. The minimum value of nitrite was recorded at $\mathrm{J} 1$ site $(0.027 \mathrm{mg} / \mathrm{l})$ during January, 2001. The maximum content was observed to be $0.240 \mathrm{mg} / \mathrm{l}$ at $\mathrm{J} 2$ site in August, 2001. Nitrate did not show a definite pattern of seasonal variation over the two years (2000-2002). Peak value was observed during January, $2002(1.633 \mathrm{mg} / \mathrm{l})$ at $\mathrm{J} 2$ site. Comparatively low value $(0.303$ $\mathrm{mg} / \mathrm{l}$ ) was recorded during June, 2001 at $\mathrm{J} 2$ site. The phosphate content was minimum during February, $2000(0.118 \mathrm{mg} / \mathrm{l})$ at S3 site while the highest value was observed during June, $2000(1.453 \mathrm{mg} / \mathrm{l})$ at S2 site. The peak value of $\mathrm{J} 2$ site was higher than of $\mathrm{J} 1$ and $\mathrm{J} 3$ site.

\section{Statistical analysis \\ Pearson's correlation coefficient}

Pearson's correlation coefficient was calculated to determine a relationship among the physico-chemical characteristics of water of Santragachi and Joypur Jheel. Significant results at $5 \%$ and $1 \%$ level were denoted by single asterisk $(*)$ and double asterisk $(* *)$ respectively in the Tables 2 and 3. Negative $r$ values prefixed by (-) sign and positive values are without any prefix in the respective tables.

Transparency was found to have a negative significant correlation with water temperature, $\mathrm{BOD}, \mathrm{COD}$, free $\mathrm{CO}_{2}$, total alkalinity, conductivity, $\mathrm{CaCO}_{3}$ hardness, TSS, TDS, chloride, ammonia and phosphate in the Santragachi Jheel. It did not show any significant relationship with $\mathrm{pH}$, dissolved oxygen, total alkalinity, conductivity and nitrite. It showed positive relationship with $\mathrm{pH}\left(\mathrm{r}=0.8157^{* *}\right)$. Transparency had highest negative correlation with Phosphate $\left(\mathrm{r}=-0.8059^{* *}\right)$ in Santragachi Jheel. $\mathrm{pH}$ showed negative correlation with BOD, $\mathrm{COD}$, free $\mathrm{CO}_{2}$, TDS, chloride and phosphate in the Santragachi Jheel and with nitrite in the Joypur Jheel. Highest negative correlation was found only with BOD $(\mathrm{r}=-0.7158 * *)$ in Santragachi Jheel. Dissolved oxygen had 
A Patra, K.B. Santra and C.K. Manna / Our Nature (2010) 8: 185-203

a positive correlation only with $\mathrm{NO}_{3}(\mathrm{r}=$ $\left.8704^{*}\right)$ in Santragachi Jheel. It exhibited strong negative relationship with ammonia $(\mathrm{r}=-0.8641 * *)$ in Santragachi Jheel. However, DO showed negative relationships with water temperature, BOD, $\mathrm{COD}$, free $\mathrm{CO}_{2}$, total alkalinity, conductivity, TDS, TSS, chloride and ammonia. Biological oxygen demand showed negative $r$ value with transparency, $\mathrm{pH}, \mathrm{DO}$ and $\mathrm{NO}_{3}$. It represented positive relationship with water temperature, COD, free $\mathrm{CO}_{2}$, total alkalinity, conductivity, $\mathrm{CaCO}_{3}$ hardness, TSS, chloride, ammonia and phosphate. It exhibited highest positive correlation $(P<0.01)$ with ammonia $(\mathrm{r}=$ $\left.0.9501^{* *}\right)$ in Joypur Jheel. Chemical oxygen demand expressed correlation with 14 parameters (10 positive and 4 negative) in Santragachi Jheel and with 9 parameters (8 positive and 1 negative) in Joypur Jheel. Free $\mathrm{CO}_{2}$ had positive correlation with 11 parameters in Santragachi Jheel and with 6 parameters in Joypur Jheel. Transparency showed negative relationship with free $\mathrm{CO}_{2}$ in both the jheels. Total alkalinity expressed highest positive correlation with TDS in both the jheels $\left(\mathrm{r}=0.9599^{* *}\right.$ in Santragachi Jheel and $\mathrm{r}=0.5910^{* *}$ in Joypur Jheel). Conductivity showed maximum positive $r$ value, $0.8928^{* *}$ with total alkalinity in Santragachi Jheel and with ammonia ( $\mathrm{r}=$ $0.5239^{* *}$ ) in Joypur Jheel. $\mathrm{CaCO}_{3}$ hardness projected positive correlation with water temperature, $\mathrm{BOD}, \mathrm{COD}$, free $\mathrm{CO}_{2}$, conductivity, TSS, TDS, chloride, ammonia and phosphate. It expressed negative correlation with transparency $\left(\mathrm{r}=-0.7066^{* *}\right.$ in Santragachi Jheel and $\mathrm{r}=-0.6228^{* *}$ in Joypur Jheel). For total suspended solid most of the physico-chemical parameters of water showed positive $r$ value ( 8 parameters in Santragachi Jheel and 7 parameters in
Joypur Jheel). Only transparency shows negative correlation with TSS $(\mathrm{r}=$ $0.6894^{* *}$ in Santragachi Jheel and $\mathrm{r}=$ $0.4306^{*}$ in Joypur Jheel). Total dissolved solid showed positive correlation with 11 parameters in Santragachi Jheel and 9 parameters in Joypur Jheel. Highest positive correlation was found with total alkalinity ( $\mathrm{r}$ $\left.=0.9599^{* *}\right)$ in Santragachi Jheel and with BOD $\left(\mathrm{r}=0.7485^{* *}\right)$ in Joypur Jheel. It had negative correlation with transparency, $\mathrm{pH}$ and dissolved oxygen in Santragachi Jheel. Chloride exhibited positive correlation with water temperature, $\mathrm{BOD}, \mathrm{COD}$, total alkalinity, conductivity, $\mathrm{CaCO}_{3}$ hardness, TSS, TDS, ammonia and phosphate in Santragachi Jheel. 3 parameters, i.e., transparency, $\mathrm{pH}$ and DO in Santragachi Jheel and 1 parameter i.e., transparency in Joypur Jheel showed negative correlation with chloride $(P<0.01)$. Highest negative correlation was found with transparency ( $\mathrm{r}=$ -8.016**). Ammonia had positive correlation with 9 parameters (water temperature, $\mathrm{BOD}, \mathrm{COD}$, free $\mathrm{CO}_{2}$, total alkalinity, $\mathrm{CaCO}_{3}$ hardness, TDS, chloride, phosphate) in Santragachi Jheel and with 10 parameters (water temperature, BOD, COD, free $\mathrm{CO}_{2}$, total alkalinity, conductivity, $\mathrm{CaCO}_{3}$ hardness, TDS, TSS and Chloride) in Joypur Jheel. It showed negative correlation with transparency and DO in both the Jheels. Nitrite showed no significant correlation with any parameters studied in Santragachi Jheel except nitrate $\left(\mathrm{r}=-0.8147^{* *}\right)$. In Joypur Jheel it exhibited negative correlation $(P<0.01)$ with $\mathrm{pH}(\mathrm{r}=-$ $0.6427 * *)$. Nitrate content of water exhibited positive correlation with DO in both jheels $\left(\mathrm{r}=0.8704^{* *}\right.$ in Santragachi Jheel and $r=0.6696^{* *}$ in Joypur Jheel). It showed significant negative correlation with 8 parameters in Santragachi Jheel and 2 
A Patra, K.B. Santra and C.K. Manna / Our Nature (2010) 8: 185-203

Table 1. Physico-chemical characteristics of water of Santragachi and Joypur Jheel (February, 2000 - January, 2002)

\begin{tabular}{|c|c|c|c|c|}
\hline \multirow{2}{*}{$\begin{array}{l}\text { Physico-chemical } \\
\text { characteristics }\end{array}$} & \multicolumn{2}{|c|}{ Santragachi Jheel } & \multicolumn{2}{|c|}{ Joypur Jheel } \\
\hline & $\overline{\text { Range }}$ & Mean \pm S.D. & Range & Mean \pm S.D. \\
\hline Water temperature ( C) & $19.67-33.85$ & $27.58 \pm 3.29$ & $19.62-33.44$ & $27.62 \pm 3.19$ \\
\hline Transparency $(\mathrm{cm})$ & $22.60-85.75$ & $56.42 \pm 8.58$ & $54.67-95.33$ & $73.82 \pm 6.51$ \\
\hline $\mathrm{pH}$ & $7.14-8.58$ & $7.48 \pm 0.49$ & $7.60-8.50$ & $7.79 \pm 0.43$ \\
\hline $\mathrm{DO}\left(\mathrm{mg} . \mathrm{l}^{-1}\right)$ & $2.39-8.73$ & $6.04 \pm 1.59$ & $5.73-14.76$ & $9.07 \pm 1.03$ \\
\hline $\mathrm{BOD}\left(\mathrm{mg} . \mathrm{l}^{-1}\right)$ & $9.11-50.93$ & $30.48 \pm 6.05$ & $4.12-21.18$ & $11.70 \pm 3.48$ \\
\hline $\mathrm{COD}\left(\mathrm{mg} . \mathrm{l}^{-1}\right)$ & $38.50-272.00$ & $163.32 \pm 31.48$ & $19.27-68.34$ & $48.75 \pm 21.41$ \\
\hline Free $\mathrm{CO}_{2}\left(\mathrm{mg} \mathrm{l}^{-1}\right)$ & $0.00-11.24$ & $4.10 \pm 1.12$ & $0.00-2.74$ & $0.90 \pm 0.32$ \\
\hline Total alkalinity $\left(\mathrm{mg} . \mathrm{l}^{-1}\right)$ & $129.79-233.00$ & $183.12 \pm 31.18$ & $114.94-144.41$ & $133.58 \pm 26.18$ \\
\hline Conductivity $\left(\mu \mathrm{mos} . \mathrm{cm}^{-1}\right)$ & $412.20-1536.80$ & $898.53 \pm 111.58$ & $303.33-550.67$ & $437.20 \pm 53.28$ \\
\hline $\mathrm{CaCO}_{3}$ hardness $\left(\mathrm{mg} . \mathrm{l}^{-1}\right)$ & $140.81-299.12$ & $223.72 \pm 29.48$ & $101.72-137.04$ & $125.91 \pm 20.15$ \\
\hline Total suspended solid (mg.l $\left.{ }^{-1}\right)$ & $108.02-264.54$ & $199.52 \pm 60.28$ & $95.39-153.07$ & $118.25 \pm 38.93$ \\
\hline Total dissolved solid (mg. $\left.{ }^{-1}\right)$ & $322.00-809.38$ & $569.38 \pm 75.39$ & $209.80-332.39$ & $275.39 \pm 50.28$ \\
\hline Chloride $\left(\mathrm{mg} . \mathrm{l}^{-1}\right)$ & $54.80-191.40$ & $131.71 \pm 31.98$ & $69.88-136.24$ & $107.25 \pm 21.18$ \\
\hline $\operatorname{Ammonia~(mg.l^{-1})}$ & $0.23-8.46$ & $3.10 \pm 0.28$ & $0.00-2.17$ & $0.81 \pm 0.11$ \\
\hline Nitrite $\left(\mathrm{mg} . \mathrm{l}^{-1}\right)$ & $0.06-0.45$ & $0.17 \pm 0.10$ & $0.03-0.24$ & $0.10 \pm 0.04$ \\
\hline Nitrate $\left(\mathrm{mg} . \mathrm{l}^{-1}\right)$ & $0.17-2.88$ & $1.01 \pm 0.25$ & $0.30-1.63$ & $0.34 \pm 0.09$ \\
\hline Phosphate $\left(\mathrm{mg} . \mathrm{I}^{-1}\right)$ & $0.18-3.43$ & $1.30 \pm 0.31$ & $0.12-1.45$ & $0.79 \pm 0.19$ \\
\hline
\end{tabular}
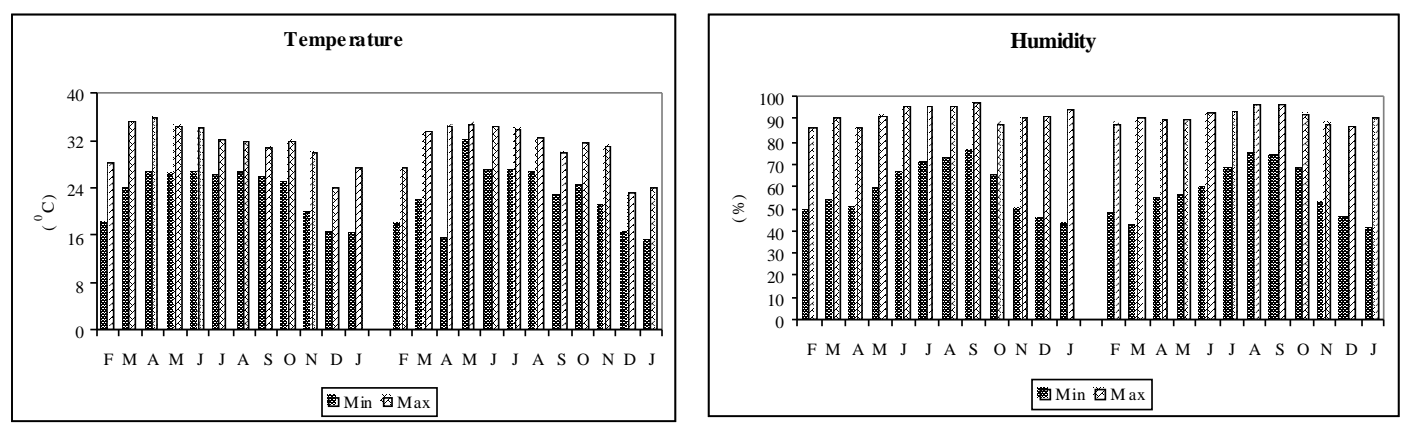

F igure 2A: C limatologic al conditions (Te mperature and Hu midity) of the stu dy area
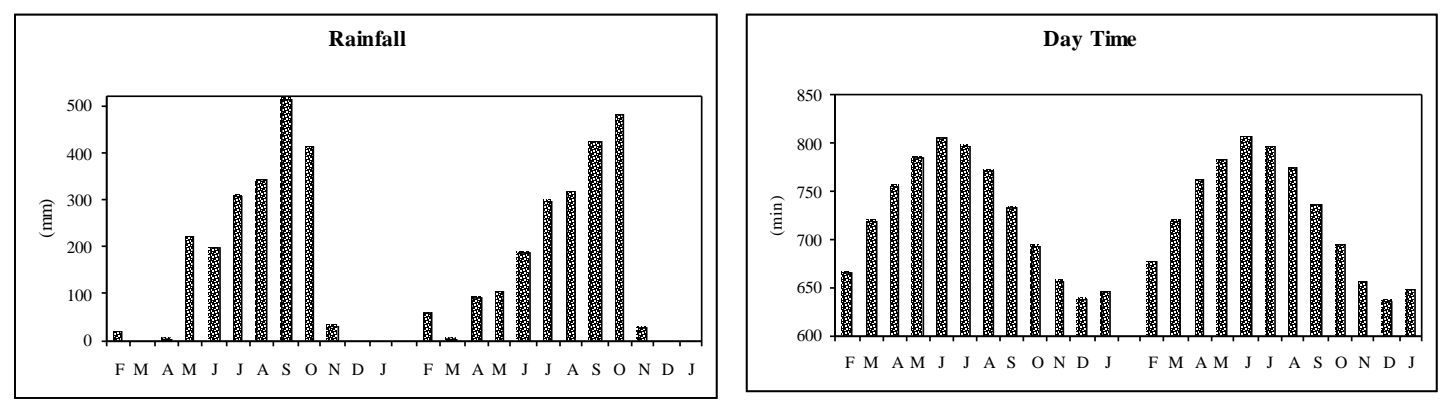

Figure 2B: Climatologic al conditions (Ra infall and Daytime) of the study area 
A Patra, K.B. Santra and C.K. Manna / Our Nature (2010) 8: 185-203
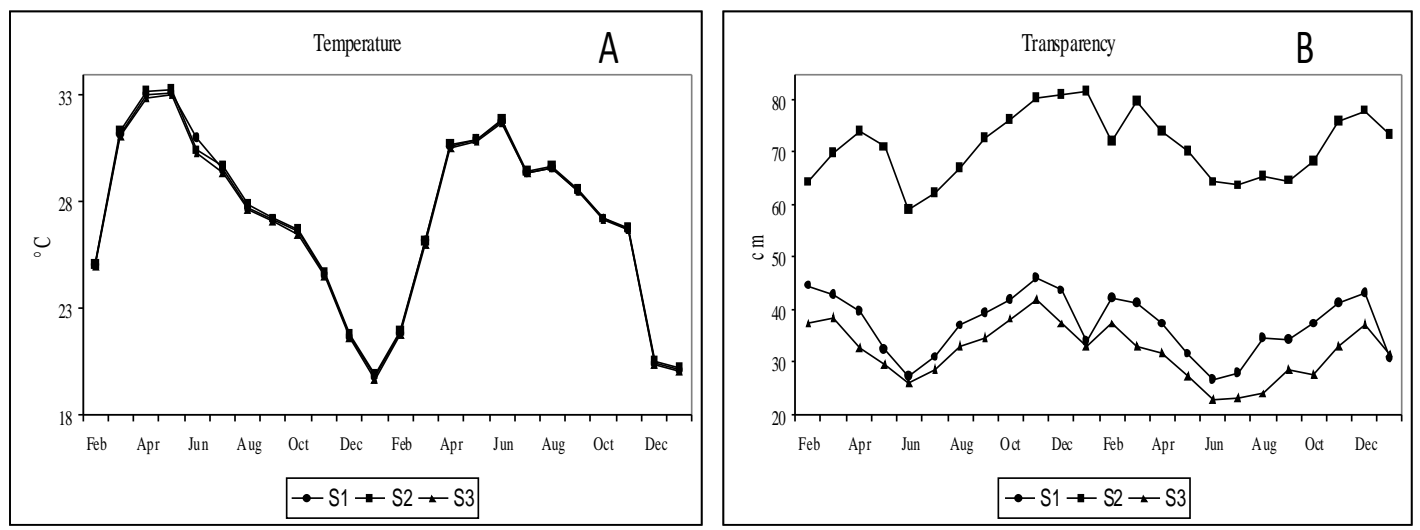

Figure 3(A-B): Station wise monthly variations of physico-chemical characteristics of water (Temperature and Transparency) of Santragachi Jheel during the period, 2000 - 2002
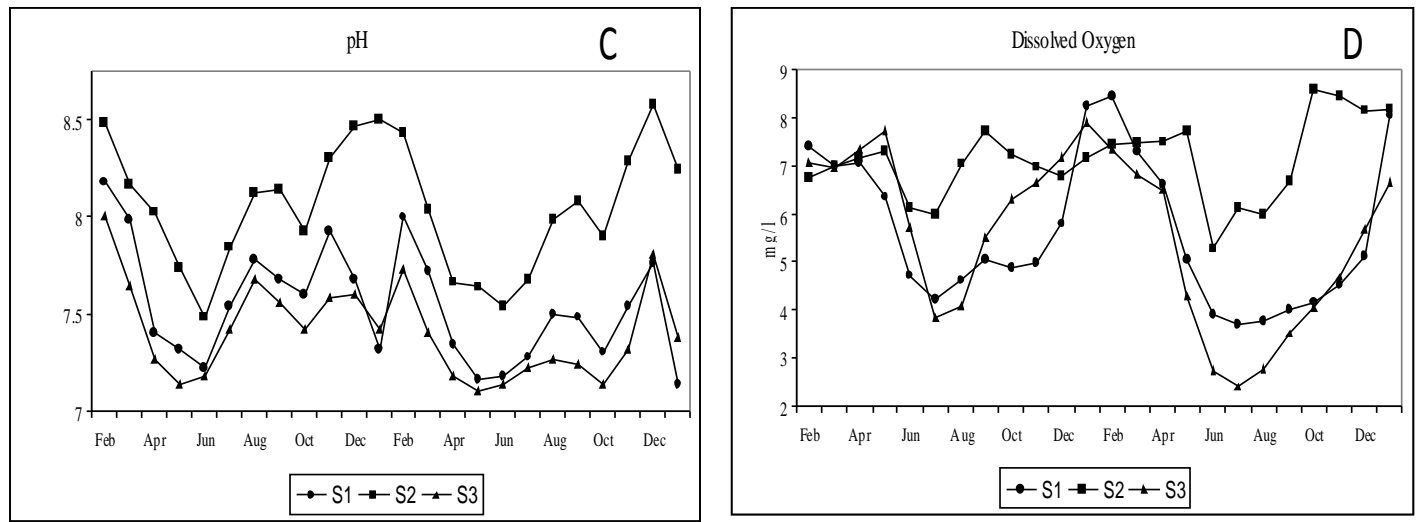

Figure 3(C-D): Station wise monthly variations of physico-chemical characteristics of water (pH and Dissolved Oxygen) of Santragachi Jheel during the period, 2000 - 2002.
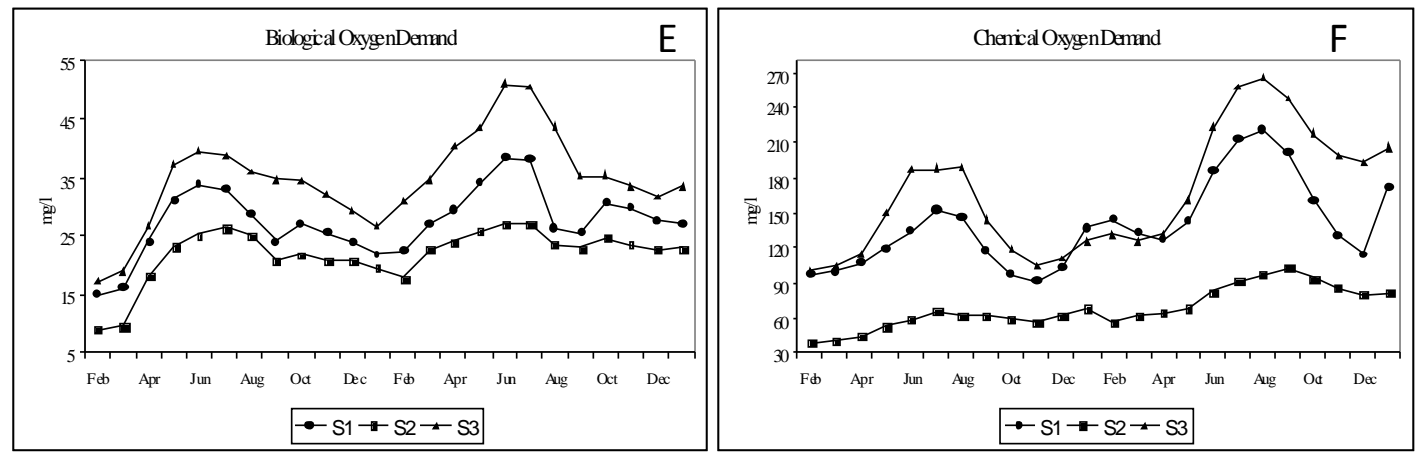

Figure 3(E-F): Station wise monthly variations of physico-chemical characteristics of water (Biological Oxygen Demand and Chemical Oxygen Demand) of Santragachi Jheel during the period, 2000 - 2002 
A Patra, K.B. Santra and C.K. Manna / Our Nature (2010) 8: 185-203
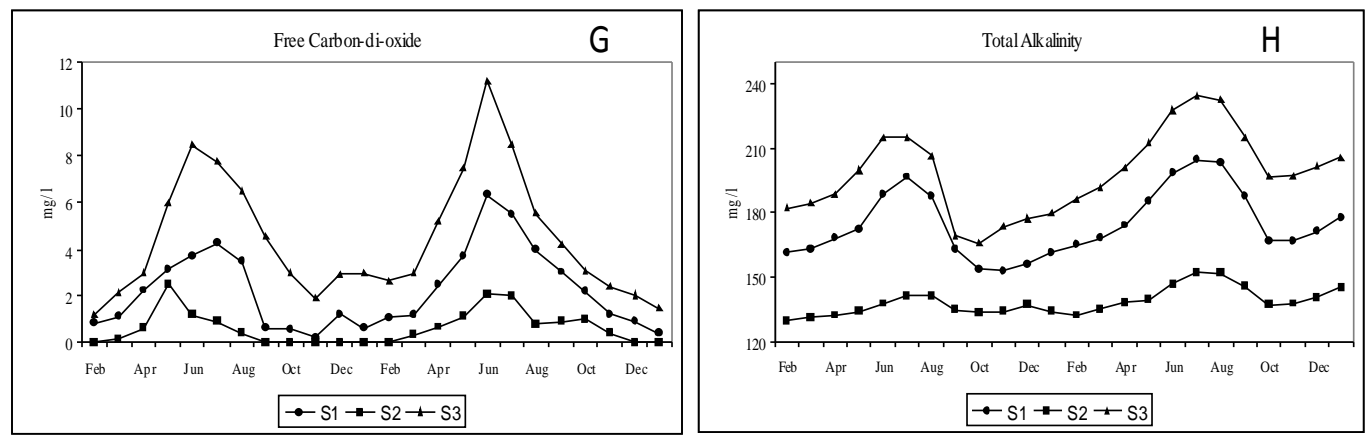

Figure 3(G-H): Station wise monthly variations of physico-chemical characteristics of water (Free Carbon-di-oxide and Total Alkalinity) of Santragachi Jheel during the period, 2000 - 2002
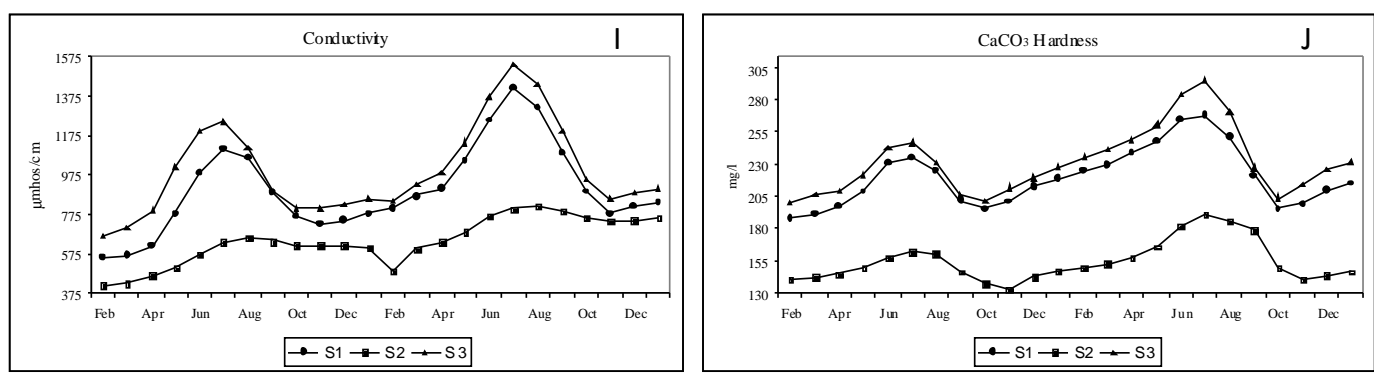

Figure 3(I-J): Station wise monthly variations of physico-chemical characteristics of water (Conductivity and $\mathrm{CaCO}_{3}$ Hardness) of Santragachi Jheel during the period, 2000 - 2002
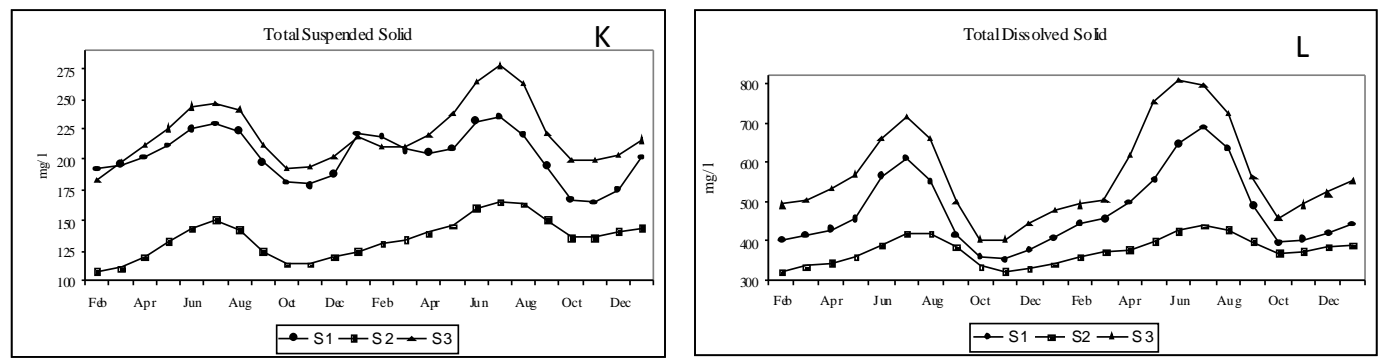

Figure 3(K-L): Station wise monthly variations of physico-chemical characteristics of water (Total Suspended Solid and Total Dissolved Solid) of Santragachi Jheel during the period, 2000 - 2002
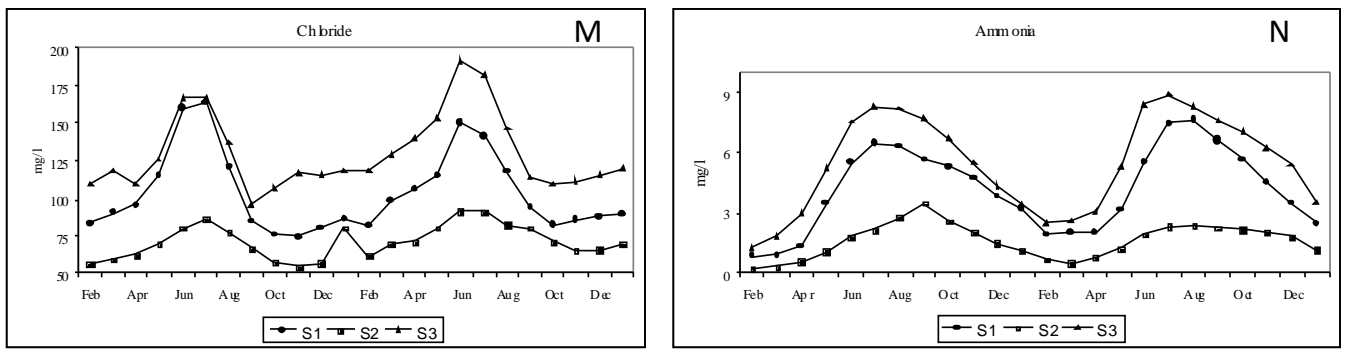

Figure 3(M-N): Station wise monthly variations of physico-chemical characteristics of $w$ ater (Chloride and Ammonia) of Santragachi Jheel during the period, 2000 - 2002 

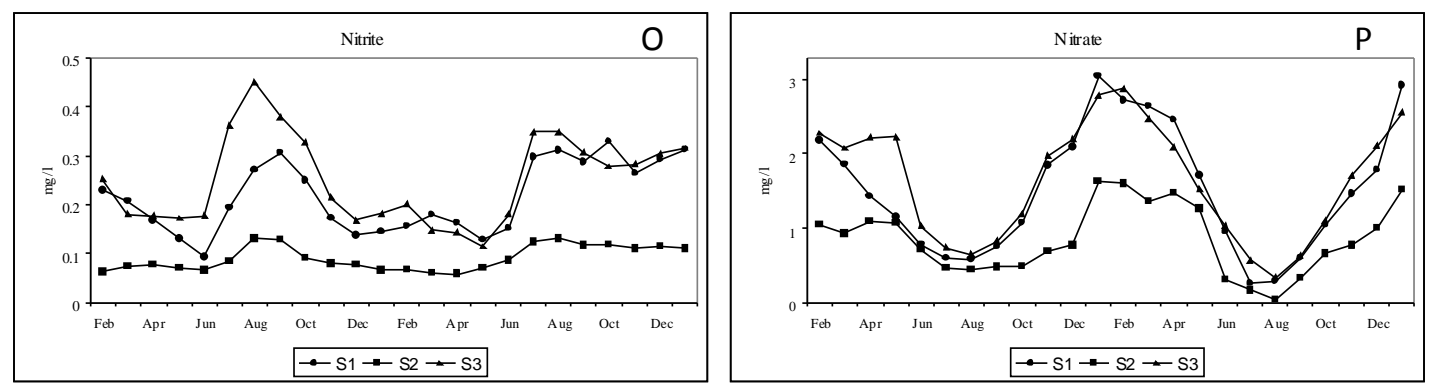

Figure 3(O-P): Station wise monthly variations of physico-chemical characteristics of water (Nitrite and Nitrate) of Santragachi Jheel during the period, 2000 - 2002

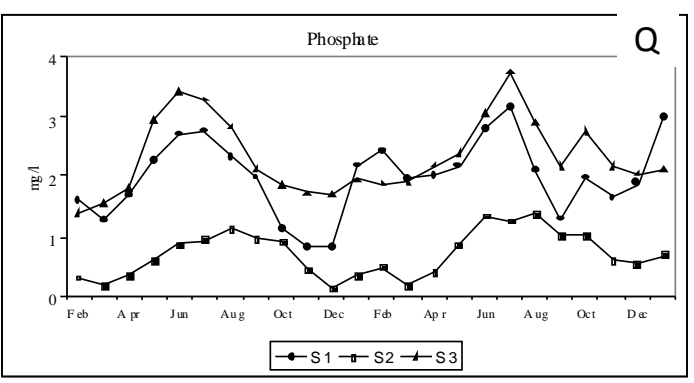

Figure 3(Q): Station wise monthly varia tions of physico-che mical characteristics of water ( $\mathrm{P}$ ho sphate) of Santragachi Jheel during the period, $2000-2002$

parameters in Joypur Jheel. Phosphate displayed positive correlation with BOD, $\mathrm{COD}$, free $\mathrm{CO}_{2}$, total alkalinity, conductivity, $\mathrm{CaCO}_{3}$ hardness, TSS, TDS and chloride in Santragachi Jheel. In Joypur Jheel it showed positive relationship with water temperature, $\mathrm{BOD}, \mathrm{COD}$, free $\mathrm{CO}_{2}$, $\mathrm{CaCO}_{3}$ hardness, TSS, TDS, chloride and ammonia. Transparency showed highest negative $\mathrm{r}$ value $(\mathrm{r}=-0.7752 * *$ in Santragachi Jheel and $\mathrm{r}=-0.8059 * *$ in Joypur Jheel) with phosphate.

\section{Discussion}

The water and air temperature is found to go more or less hand in hand presumably due to standing water and relatively small size of the water body. According to Welch (1952) smaller the body of water, more quickly it reacts to changes in the atmospheric temperature. The effect of air on the water temperature did seem to affect the mixing of water body where stratifications clearly developed during summer and winter with a spring and autumn overturn.

Transparency of water in Santragachi and Joypur Jheel was minimum during summer while maximum values were observed in the post monsoon months respectively. This revealed more or less a warm monomictic system with a spring overturn through the clear dimictic picture did not evolve by this factor alone. In $\mathrm{S} 1$ and S3 sites of Santragachi Jheel, the transparency value of water is low. It may be due to inflow of sewage effluents. It is known that low values were primarily due to turbidity and it may be due to suspended particles carried by inflow of sewage effluents in Santragachi Jheel. In the present observation transparency has the inverse relationship with TSS. The values, however, are indicative of eutrophication irrespective of the stations. This has been well documented by Loffler (1969); Rodhe et al. (1966); Krishnyya and Laal (1990); Ramana and Sreeramulu (1994); Saijo et al. (1997); Sedamkar and Angadi (2003).

$\mathrm{pH}$ of the two jheels remained mostly alkaline throughout the period of 
investigation as observed by Sarwar and Wazir (1991); Kartha and Rao (1992) ; Kumar (1995). It virtually showed very little variation on monthly basis. In Joypur Jheel, the $\mathrm{pH}$ is higher and this can be ascribed to higher photosynthetic activity by the macrophytes. Hutchinson et al. (1929) have asserted that the high $\mathrm{pH}$ is associated with the phytoplankton maxima.

Dissolved oxygen showed a very clear picture. The increase of oxygen during winter months as in the present observation could be attributed to low temperature (Alfred and Thapa, 1996). The oxygen deficit during summer is a characteristic feature of a productive wetland (Sreenivasan, 1970; Timms, 1970). Thus oxygen content during summer in Santragachi Jheel indicates the nature of this Jheel. Decomposition acts as the key role on oxygen content in nutrient rich tropical wetland where organic pollution is high and has very little oxygen dissolved in them (Sharma et al, 1981; Jakher and Rawat, 2003). It supports the findings in Santragachi Jheel. However, oxygen holding capacity of water reduces at higher temperature (Mustafa and Ahmed, 1982).

BOD values indicate that Santragachi jheel can be placed in a class of wetland, i.e., eutrophic as per classification of Prati et al. (1971). Maximum values of BOD have been recorded in summer and in general it is found that the water of sewage sites has higher BOD values. Low values of BOD in winter may be due to lesser quantity of total solids/dissolved solids/suspended solids. The present observation agrees with the findings of Pathak and Shastree (1993); Sharma and Gupta (1994); Maya (2003).

The COD values convey the quantity of oxidisable organic matter in the water. The increase of COD during summer in both the Jheels is correlated with the decomposition of suspended organic matter which releases the soluble organic matter in the water. This type of relationship is also observed by Goel et al. (1980); Varghese et al. (1992); Osborne and Totme (1994); Pejaver et al. (2002). The decrease in COD during the rainy season is due to dilution of dissolved organic matter. The high value of COD in Santragachi Jheel during summer season is due to low water level and high decomposition rates.

Free $\mathrm{CO}_{2}$ in the water body, generally appears when the oxygen remains low or absent. The minimum value of $\mathrm{FCO}_{2}$ was observed in January in both the Jheels. The peak value of this parameter was observed in summer months which might be due to decomposition of organic matter by microbes in the bottom resulting in the rapid production of free Carbon-di-oxide as has also been reported by Welch (1952) ; Antwi and Ofori-Danson (1993).

The increase in total alkalinity during summer months in both the jheels appears to be due to the concentration of nutrients in water. Adebisi (1980) showed alkalinity to be inversely correlated with the water level. During winter, due to slow decomposition of organic matter, $\mathrm{CO}_{2}$ production is less. Dilution plays an important factor in lessening the alkalinity values (Chakraborty et al., 1959). The total alkalinity remains always higher in eutrophic water (Osborne and Totme, 1994; Craft, 1997). Average values were higher in Santragachi Jheel than Joypur Jheel indicating higher trophic status of the Santragachi Jheel (Maya, 2003).

Water becomes a conductor of electrical current when substances are dissolved in it and the conductivity is proportional to the amount of dissolved substances (Michael, 1984). The present 
A Patra, K.B. Santra and C.K. Manna / Our Nature (2010) 8: 185-203

observation about the relationship between conductivity and TDS (positive $r$ value) is very much similar to the findings of Michael (1984). Conductivity decreased during winter followed by progressive increase in summer as also recorded by Sharma et al. (1978), Varghese et al. (1992), Pathak and Shastree (1993), Detenbeck (1996) and Chandrasekhar (2003). Conductivity was maximum in May-June when the water level in the two Jheels was minimum.

The maximum values of $\mathrm{CaCO}_{3}$ hardness were recorded during summer in both the jheels which had a decreasing trend in monsoon and reaching lowest values in winter. During winter, decomposition of organic matter became reduced and $\mathrm{CO}_{2}$ is not liberated into the aquatic medium. Generally the dilution of hardness depends with the advent of rains (Chakraborty et al., 1959; Goldman and Wetzel, 1963; Sreenivasan 1964a; Easley et al., 1994; Mulholland et al., 1997) and increases with the decrease in water levels (SubhoRao and Govind, 1964; D'Angelo et al., 1994).

Total suspended solid and total dissolved solid values were maximum in summer and minimum in winter. This observation is very much similar to the findings of Saha et al. (1971). Total suspended solid and total dissolved solid was higher in Santragachi Jheel than Joypur Jheel. It may be due to receiving the sewage water and suspended substances from the surrounding areas. Similar observations were also recorded by Goel et al. (1980), Schwartz and Gruendling (1985), D’Angelo and Reddy (1994).

Premonsoon showed highest chloride values when water level was low followed by monsoon and post monsoon with high water levels. Such condition is also observed by Jana (1973) and Swarnalatha and NarsingRao (1998) who found the rise of chlorides due to increased summer temperature and evaporation. The high amounts of chloride in freshwaters have been considered generally due to pollution. High concentration of chloride content reflects the increasing pollution in Santragachi Jheel.

Ammonia is usually present in the aquatic ecosystem as the dissociated ammonium ion $\left(\mathrm{NH}_{4}^{+}\right)$. The highest ammonia content is also observed to correspond with the period of high decomposition rate. The presence of higher amounts of ammonia and ammonium compounds in the sewage fed polluted water bodies has been emphasized by many authors (Nandan and Patel, 1985; Schwartz and Gruendling, 1985). In this study, the value of ammonia in Santragachi Jheel is higher than Joypur Jheel confirming a high degree of pollution by organic matter in this jheel. In summer, ammonia may also be released due to anoxic conditions (Mortimer, 1971; Sikora et al., 1995).

Nitrite is an intermediate compound of nitrogen reduction or ammonia oxidation and mostly found in the sewage contaminated water bodies (Andersen, 1974). Due to very unstable nature of nitrite it shows no definite pattern of seasonal cyclicity. However, Andersen and Jenson (1992); Jakher and Rawat (2003) found a positive correlation between nitrite and nitrate.

Within an aquatic system nitrate is primarily of animal origin (Thresh et al., 1944). Ganapati (1957) pointed out that the tropical waters; particularly unpolluted ones are deficient in nitrates. In Santragachi Jheel the nitrates are relatively much higher than the limit. Nitrate value was higher in winter 
A Patra, K.B. Santra and C.K. Manna / Our Nature (2010) 8: 185-203

and lower in summer in both the jheels. Hutchinson (1967); Munawar (1970) observed similar trend and suggested that in summer, denitrifying bacteria breakup nitrates into nitrites and ammonia. In winter, however, the activities of these bacteria goes down (Kaur et al., 1996), resulting in higher nitrate value in winter in these two jheels. The fairly high amount of nitrate during winter and low in summer in Santragachi Jheel are correlated with the amounts of dissolved oxygen.

Alikunhi et al. (1955) pointed out that it is difficult to draw any correlation of nitrates with any other physico-chemical factors while according to Fillos and Swanson (1975) the nitrates are a prime index of immediate fertility of water. These findings confirm the present observations also.

Among the major nutrients, the importance of phosphates in water bodies is well documented (Vollenweider, 1968; Vaithiyanathan, 1993; Dortch, 1996; Chandrasekhar et al., 2003). Thomas (1969); Niswander and Mitsch (1995) pointed out that the addition of phosphate brings about an eutrophication mechanism by increasing the bacterial content, increase in oxygen demand, increase in production of growth factors for the algae and lastly the increase in growth of algae. The increased phosphate levels also indicate high degree of pollution. Willem et al. (1972) found that total phosphate was always higher at the polluted points in comparison to nonpolluted points of the water bodies. This finding supports the present observations as phosphate content in Santragachi Jheel is greater than Joypur Jheel and sewage sites have more phosphate than non sewage sites ( S2 site < S1 site < S3 site in Santragachi Jheel). High amount of phosphate in
Santragachi Jheel during summer season may be due to the concentration of nutrients in water and possible release of phosphate from sediments. The reverse pattern of phosphate and nitrate concentrations like the present observation in some shallow eutrophic water bodies has been observed by Philips (1977);Vaithiyanathan and Richardson (1997). Increment of phosphorus is often associated with increase of ammonia in summer. This may be due to sediment release.

Edmondson (1970) suggested that the nitrate - phosphate ratio $(\mathrm{N}: \mathrm{P})$ in water body could be used diagnostically to indicate the degree of pollution by sewage. The N:P ratio can also be used to show the recovery rates after the diversion of the sewage from the water bodies. The present observations are in conformity with these findings. The ratio is high (>1) in Joypur Jheel (relatively non-polluted) while in Santragachi Jheel the ratio less than one in most of the seasons shows it to be highly polluted water body.

The physico-chemical characteristics of water of Santragachi and Joypur Jheel indicate that the water of Santragachi Jheel is richer regarding nutrient as well as pollutional status than the Joypur Jheel. The raw domestic sewage and effluents from cattle shed are the main cause for the deterioration of water of the Santragachi Jheel. The presence of free $\mathrm{CO}_{2}$ content at sewage affected sites is an effect of microbial activity of converting organic wastes into water. The high quantity of ammonia during summer months in Santragachi Jheel denotes the high decomposition rates of organic matters at that time and for the need of decomposition, dissolved oxygen content was depleted. Oxygen depletion often results during the period of high decomposition and low water 
A Patra, K.B. Santra and C.K. Manna / Our Nature (2010) 8: 185-203

level i.e., summer season. A high amount of TSS at summer at sewage sites of the Santragachi Jheel reduces the transparency of water also. Due to high content of organic materials BOD is also increased. Sedimentation as well as sewage contamination is the main cause of increased nitrate and phosphate content. The major changes of these physico-chemical features lead to the high pollutional status of the Santragachi Jheel observed in this investigation.

\section{Acknowledgements}

The authors express their heartiest thanks to the authority of the Udainarayanpur High School for giving permission to the first author. Thanks are also extended to the Authority of Santragachi and Joypur jheel to carry out this type of work.

\section{References}

Adebisi, A.A. 1980. The physico-chemical hydrology of a tropical seasonal upper Ogun river. Hydrobiol. 79: 157-165.

Alfred, J.R.B. and M.P. Thapa 1996. Limnological investigations on Ward's lake- A wetland in Shilong, Meghalaya, W.E. India. Rec. Zool. Surv. India. Occa. Pap. 169: 1-125.

Alikunhi, K.H., H. Chaudhuri and V. Ramachandran 1955. On the mortality of carp fry in nursery ponds and the role of plankton in their survival and growth. Ind. J. Fish. 3 (2): 257 315.

Anderson, F.O. and H.S. Jenson 1992. Regeneration of inorganic phosphorus and nitrogen from decomposition of seston in a freshwater sediment. Hydrobiol. 228(1): 71-81.

Anderson, R.S. 1974. Crustacean plankton communities of 340 lakes and ponds in and near the National Park of the Canadian Rocky mountains. J. Fish. Res. Bd. Can. 31: 855869.

Ansari, A.H. and S. Kumar 2003. Effect of nitrate input on the release of phosphorus from a tropical lake sediment. Dimens. Polln. 2: 120-126.

Antwi, L.A.K. and P.K. Ofori-Danson 1993. Limnology of a tropical reservoir (The Kpong Reservoir in Ghana). Trop. Ecol. 34(1): 7587.

APHA 1989. Standard methods for the examination of water and wastewater. $17^{\text {th }}$ edition, American Public Health Association, Washington, D.C.

Bhatt, S.D. and J.K. Pathak 1989. Assessment of water quality and aspects of pollution in a stretch of river Gomti (Kumaun: Lesser Himalaya). J. Env. Biol. 10(4): 28-32.

Chakraborty, R.D., P. Roy and S.B. Singh 1959. A quantitative study of plankton and physicochemical study of the river Jamuna at Allhabad in 1954-55. Ind. J. Fish. 6(1): 186203.

Chandrasekhar, J.S., B.K. Lenin and R.K. Somasekher 2003. Impact of urbanization on Bellandur lake, Bangalore- a case study. $J$. Environ. Bio. 24(3): 223-227.

Clair, T.A., B.G. Sayer, J.R. Kramer and D.R.Eaton 1996. Seasonal variation in the composition of aquatic organic matter in some Nova Scotion brown waters : A nuclear resonance approach. Hydrobiologia. 317(2): 141-150.

Craft, C.B. 1997. Dynamics of nitrogen and phosphorus retention during wetland ecosystem succession. Wetlan. Ecol. Manage. 4(3): 177-187.

D' Angelo, E.M. and K.R. Reddy 1994. Diagenes is of organic matter in a wetland receiving hypereutrophic lake water: I. Distribution of dissolved nutrients in the soil and water column. J. Environ. Qual. 23(5): 928-936.

Das, N.K. and R.K. Sinha 1994. Pollution status of river Ganga at Patna (Bihar), India. $J$. Freshwater. Biol. 6(2): 159 - 164.

Detenbeck, N.E., D.L. Taylor, A. Lima and C. Hagley 1996. Temporal and spatial variability in water quality of wetlands in the Minneapolis/St. Paul, MN metropolitan area: Implications for monitoring strategies and designs. Environ. Monit. Assess. 40(1): 1140. 
A Patra, K.B. Santra and C.K. Manna / Our Nature (2010) 8: 185-203

Dortch, M.S. 1996. Removal of solids, nitrogen and phosphorus in the Cache River wetland. Wetlands 16(3): 358-365.

Easley, W.S., L.E. Barness-Walz, P.L. Neichter and J.A. Bohannon 1994. Evaluation of water quality in Taylorsville lake, Eentucky, using the CE-Qual-W2 model. Lake Reserv. Manage. 9(2): 71-72.

Edmondson, W.T. 1970. Phosphorus, nitrogen and algae in lake Washington after diversion of sewage. Science 169: 690-691.

Ellis, M.M., B.A. Westfall and M.D. Ellis 1946. Determination of Water Quality. Fish and Wild-life Service., U.S. Dept. Interior. Res. Rept. 9. pp. 122.

Fillos, J. and W.R. Swanson 1975. The release of nutrients from river and lake sediments. $J$. Wat. Pollut. Cont. Fed. 47: 1032-1041.

Freeman, C., M.A. Lock and B. Reynolds 1993. Climatic change and the release of immobilized nutrients from Welsh riparian wetland soils. Ecol. Eng. 2(4): 367- 373.

Ganapati, S.V. 1957. Limnological studies of two upland waters in Madras State. Arch. Hydrobiol. 56: 30-61.

Goel, P.K., B. Gopal and R. Trivedi 1980. Impact of sewage on freshwater ecosystems. II. Physicochemical characteristics of water and their seasonal changes. Int. J. Ecol. Environ. Sci. 6: 97-116.

Goldmen, C.R. and R.G. Wetzel 1963. A study of the primary productivity of Clear lake, Lake County, California. Ecology 44: 283-294.

Golterman, H.L. (Ed.) 1969. Methods of chemical analysis of freshwaters. IBP Handbook No. 8, Blackwells, Oxford.

Golterman, H.L. and N.T. Qude 1991. Eutrophication of lakes, rivers and coastal seas. In The handbook of environmental chemistry (Ed. O. Hutzinger). Berlin Heidelberg, SpringerVerlag 5(A): 70-124.

Hemasundaram, A., K. Dhanalakshmi, B. Prasad and N.V.S. Naidu 2003. Assessment of water quality with regard to surfactants in pilgrim town - a case study of Tirupati. Ultr. Scient. Phyl. Sci. 15(2): 189-194.

Hutchinson, A.H., S.C. Lucas and M. McPhail 1929. Seasonal variations in the chemical and physical properties of the culture of the strait of Georgia in relation to phytoplankton. Trans. Roy. Soc. Canada 3: 177-183.

Hutchinson, G.E. 1967. A treatise on Limnology. II. Introduction to lake Biology and Limnoplankton. John Wiley and Sons. Inc., NewYork, USA.

Jakher, G.R. and M. Rawat 2003. Correlation of nitrate and most probable number for sewagefed pond, Gulab Sagar at Jodhpur city. Oikoassay 16(1): 13-14.

Jana, B.B. 1973. Seasonal periodicity of plankton in freshwater pond in West Bengal, India. Hydrobiol. 58: 127-143.

Jothimani, P. and A. Bhaskaran 2003. Effects of dilution and dynamics of physical factors during factory effluent irrigation. $J$. Ecotoxico. Environ. Monit. 12(4): 255-261.

Kajak, Z. 1979. Eutrofizacja jezior (Eutrophication of lakes). Warszawa, PWN. 233 p.

Kartha, K.V. and K.S. Rao 1992. Environmental status of Gandhisagar reservoir. Fish. Technol. 29(1): 14-20.

Kaur, V.B., K.S. Bath and G. Mandar 1996. Abiotic and biotic components of a freshwater pond of Patiala (Punjab). Poll. Res. 15(3): 253-256.

Krishnayya, C.H.G. and A.K. Laal 1990. Eutrophication, its causes and consequences with particular reference to Kolleru lake. In Recent Trends in Limnology (Eds. V.P. Agarwal and P. Das). pp. 145-149.

Kumar, A. 1995. Some limnological aspect of the fresh water tropical wetlands of Santhal Pargana (Bihar) India. J. Environ. Poll. 2(3): 137-141.

Loffler, H. 1969. High altitude lakes in Mount Everest region. Verh. Int. Verin. Limnol. 17: 373-385.

Maya, S. 2003. Pollution assessment of selected temple tanks of Kerala. Natur. Env. Poll. Techno. 2(3): 289-294.

Michael, P. 1984. Ecological methods for field and laboratory investigations. Tata-McGraw Hill Pub. Com. Ltd., New Delhi. 404 p.

Mortimer, C.H. 1971. Chemical exchanges between sediments and water in Great lakesspeculations on probable regulatory mechanisms. Limnol. Oceanogr. 16: 387-404. 
A Patra, K.B. Santra and C.K. Manna / Our Nature (2010) 8: 185-203

Mulholland, P.J., G.R. Best, C.C. Coutant, G.M. Hornberger and R.G. Wetzel 1997. Effect of climate change on freshwater ecosystems of the South-eastern United States and the Gulf Coast of Maxico. 1994. Freshwat. Ecosys. Climat. Chang. 11(8): 949-970.

Munawar, M. 1970. Limnological studies on freshwater ponds of Hyderabad, India. II. The biocenose distribution of unicellular and colonial phytoplankton in polluted and unpolluted environments. Hydrobiol. 36(1): 105-128.

Nandan, S.N. and R.J. Patel 1985. Eutrophication in Vishwamitri river flowing through Baroda. Geobios 12: 60-62.

Negi, V. and M.C. Pant 1983. Analysis of zooplankton community of lake Khurpatal (Kumaun Himalaya). Trop. Ecol. 24(2): 271282.

NEWS 1998. Wetlands and waterbirds of West Bengal. Vision Publications Pvt. Ltd., Calcutta. 199 p.

Niswander, S.F. and W.J. Mitsch 1995. Functional analysis of a two-year old created in stream wetland: Hydrology, phosphorus retension and vegetation survival and growth. Wetlands 15(3): $212-215$.

Osborne, P.L. and R.G. Totme 1994. Long-term impacts of sewage effluent disposal on a tropical wetland. In Wetlands sys. in water poll. control (Eds. H.J. Bavor and D.S. Mitchell). 29(4): 111-117.

Pathak, S. and N.K. Shastree 1993. Physicochemical status of the lentic hydrosphere of Rukmini and Visar Sarovar of Gaya, Bihar. Environ. Ecol. 11(1): 57-66.

Patralekh, M. and L.N. Patralekh 2004. Pollution load on some freshwater ecosystems. Environ. Ecol. 22(3): 527-533.

Pejaver, M., V. Somani and M. Borker 2002. Physicochemical studies of lake Ambegosale, Thane, India. J. Ecobio. 14(4): 277-281.

Philips, G.I. 1977. The mineral nutrient levels in three Norfalk Broads differing in trophic status and on annual mineral content budget for one of them. J. Ecol. 65: 447- 474.
Prati, L., R. Pavanello and P. Pesarin 1971. Variations in the compositions of river waters. Water Research 5: 741-751.

Qadri, M.Y. and A.R. Yusuf 1978. Seasonal variation in the physico-chemical factors of a subtropical lake in Kashmir. J. Inl. Fish Soc. India 10: 89-96.

Ramana, P.V. and K. Sreeramulu 1994. Some aspects of limnology and fishery of Vottigedda reservoir in Andhra Pradesh. J. Ecobiol. 2: 81-88.

Rodhe, W., J.E. Hobbie and R.T. Wright 1966. Phototrophy and Heterotrophy in high mountain lakes. Verh. Int. Ver. Limnol. 16: 302-313.

Saha, G.N., K.I. Sehgal, E. Mitra and A.C. Nandy 1971. Studies on the seasonal and diurnal variations in physico-chemical and biological conditions of a perennial freshwater pond. $J$. Inl. Fish Soc. India 3: 79-102.

Saijo, Y., O. Mitamura, K. Hino, I. Ikusima, T. Matsumura and V.P. Silva 1997. Physicochemical features of rivers and lakes in Pantanal wetland. Jap. J. Limnol. 58(1): 6982.

Sarwar, S.G. and M.A. Wazir 1991. Physico-chemical characteristics of a freshwater pond of Srinagar (Kashmir). Poll. Res. 10(4): 223227.

Schwatz, L.N. and G.K. Gruendling 1985. The effects of sewage on a lake Champlain wetland. $J$. Freshwat. Ecol. 3(1): 35-46.

Sedamkar, E. and S.B. Angadi 2003. Physicochemical parameters of two fresh waterbodies of Gulbarga- India, with special reference to phytoplankton. Polln. Res. 22(3): 411-422.

Seshavatharum, V. and P. Venu 1982. Some observations on the ecology of Kolleru lake. Int. J. Ecol. Environ. Sci. 7: 35-44.

Shanon, E.E. and P.L. Brezonik 1972. Relationships between lake Trophic state and nitrogen and phosphorus loading rates. Environ. Sci. Tech. 6: 719-725.

Sharma, A.P. and M.C. Pant 1979. Certain physicochemical features, phytoplankton and population and chlorophyll concentration in a high altitude lake. Trop. Ecol. 20: 101-113. 
A Patra, K.B. Santra and C.K. Manna / Our Nature (2010) 8: 185-203

Sharma, K.D., N. Lal and P.D. Pathak 1981. Water quality of sewage drains entering Yamuna at Agra. Ind. J. Environ. Hlth. 23(2): 118-122.

Sharma, K.P., P.K. Goel and B. Gopal 1978. Limnological studies of polluted freshwater. I. Physico chemical characteristics. Int. J. Ecol. Environ. Sci. 4: 89-105.

Sharma, L.L. and M.C. Gupta 1994. Some aspects of limnology of Amarchand reservoir, district Rajsamad, Rajasthan: Physical parameters. Poll. Res. 13(2): 169-179.

Sharma, M.R. and P.S. Verma 2003. Water quality of springs in Hamipur area of outer Himalayas. Polln. Res. 22(3): 369-372.

Sikora, F.J., Z. Tong, L.L. Behrends, S.L. Steinberg and H.S. Coonrod 1995. Ammonium removal in constructed wetlands with recirculating subsurface flow: Removal rates and mechanisms. In Wetland systems for water pollution control (Eds. R.H. Kadlec and $\mathrm{H}$. Brix). 32(3): 193-202.

Sivakumar, A.A., P. Arunadevi and M. Aruchami 2003. Studies on water quality of the river Ambarampalayam, Coimbatore district, Tamil Nadu. Nat. Env. Poll. Tchno. 2(3): 305-308.

SPSS 1993. Version 6.0, Chicago, USA.

Sreenivasan, A. 1964a. Limnological studies and fish yield in three upland lakes of Madras State, India. Limnol. Oceanogr. 9: 564-575.

Sreenivasan, A. 1970. Limnology of tropical impoundments: A comparative study of the major reservoirs in Madras State (India). Hydrobiol. 36(3-4): 443-469.

Subho Rao, D. and B.V. Govind 1964. Hydrology of Tungabhadra Reservoir. Ind. J. Fish. 11: 321344.

Swaranlatha, N. and A. Narsing Rao 1998. Ecological studies on Banjara lake with reference to water pollution. J. Environ. Biol. 19(2): 179186.
Thomas, E.A. 1969. The process of eutrophication in central European lakes. In Eutrophication: Causes, Consequences, Correctives. Nat. Acad. Sciences, Washington, D.C. pp. 29-49.

Thresh, J.C., Suckling and J.E. Beale 1944. The examination of water and water supplies. London Univ. Press. pp. 491-499.

Timms, B.V. 1970. Chemical and zooplankton studies of lentic habitats in North Eastern New South Wales. Aust. J. Mar. Wat. Res. 21: 11-33.

Trivedy, R.K. and P.K. Goel 1984. Chemical and biological methods for water pollution studies. Environmental Publishers, Karad, India. $304 \mathrm{p}$.

Vaithiyanathan, P. and C.J. Richardson 1997. Nutrient profiles in the Everglades: Examination along the eutrophication gradient. Sci. Tol. Environ. 205(1): 81-95.

Vaithiyanathan, P., P.K. Jha and V. Subramanian 1993. Phosphorus distribution in the sediments of the Hooghly (Ganges) Estuary, India. Estuar. Coast. Shelf. Sci. 37(6): 603614.

Varghese, M., A. Chauhan and L.P. Naik 1992. Hydrobiological studies of domestically polluted tropical pond. I. Physico-chemical characteristics. Poll. Res. 11(2): 95-100.

Vollenweider, R.A. 1968. Scientific fundamentals of the eutrophication of lakes and flowing waters with special reference to nitrogen and phosphorus as factors in Eutrophication. OECD, France. 27: pp. 182.

Welch, P. S. 1952. Limnology ( $2^{\text {nd }}$ Edition $)$. Mc.Graw - Hill Book Co., New York.

Willem, H.O., F. De Smet and M.J.C. Evens 1972. A hydrobiological study of the polluted River Lieve (Ghent, Belgium). Hydrobiol. 39(1): 91-154.

Wood, R.B. and G.E. Gibson 1974. Eutrophication and Loch Heagen. Water Res. 7: 163-287. 